\title{
Reading socio-political and spatial dynamics through graffiti in conflict-affected societies
}

DOI:

10.1080/01436597.2020.1810009

\section{Document Version}

Accepted author manuscript

Link to publication record in Manchester Research Explorer

\section{Citation for published version (APA):}

Vogel, B., Arthur, C., Lepp, E., O'Driscoll, D., \& Haworth, B. T. (2020). Reading socio-political and spatial dynamics through graffiti in conflict-affected societies. Third World Quarterly, $41(12), 2148$.

https://doi.org/10.1080/01436597.2020.1810009

\section{Published in:}

Third World Quarterly

\section{Citing this paper}

Please note that where the full-text provided on Manchester Research Explorer is the Author Accepted Manuscript or Proof version this may differ from the final Published version. If citing, it is advised that you check and use the publisher's definitive version.

\section{General rights}

Copyright and moral rights for the publications made accessible in the Research Explorer are retained by the authors and/or other copyright owners and it is a condition of accessing publications that users recognise and abide by the legal requirements associated with these rights.

\section{Takedown policy}

If you believe that this document breaches copyright please refer to the University of Manchester's Takedown Procedures [http://man.ac.uk/04Y6Bo] or contact uml.scholarlycommunications@manchester.ac.uk providing relevant details, so we can investigate your claim.

\section{OPEN ACCESS}




\title{
Reading socio-political and spatial dynamics through graffiti in conflict-affected societies
}

\author{
Birte Vogel, Catherine Arthur, Eric Lepp, Dylan O’Driscoll and Billy Tusker Haworth
}

\begin{abstract}
This paper argues that graffiti can provide a form of socio-political commentary at the local level, and is a valuable, yet often overlooked, resource for scholars and policy makers in conflict-affected societies. Graffiti, in its many forms, can provide rich insight into societies, cultures, social issues, trends, political discourse, and spatial and territorial identities and claims. Thus, this, paper suggest that graffiti is a valuable source of knowledge in societies undergoing social and political transformation to hear the voices of those often left out from the official discourses. Despite advances in the field of arts and International Relations and the focus on the local and the everyday, peace and conflict scholarship and policy still lack systematic engagement with artsbased contributions and how to read them. The paper attempts to address this gap by outlining four core dimensions to consider when attempting to interpret and decode graffiti: the spatial, temporal, political economy, and representative dimensions. This can also be viewed as an inquiry into the where, when, who and what. These four elements make up an analytical guide and enable scholars to better understand graffiti, and its political meaning and messaging.
\end{abstract}

\section{Introduction}

This paper suggests that graffiti can provide a form of socio-political commentary at the local level, and is a valuable, yet often overlooked, resource for scholars and policy makers in conflict-affected societies. Despite advances in the field of arts and International Relations and the recent 'local turn' in Peace and Conflict Studies (Mac Ginty and Richmond, 2013), scholarship and policy still lack systematic engagement with arts-based contributions and how to read them. In contrast, other disciplines have studied graffiti from various methodological backgrounds and gained insights into past and present dynamics of societies that would greatly benefit the field. As Merrill (2015: 370) summarises, criminological studies have examined graffiti as vandalism (Wilson 1987), or a means to understand the relationship between urban space, crime and control (Kindynis 2018). Historical and archaeological scholars are interested in 'mark-making practices' (Merrill 2013: 370) and the untold narratives of the past hidden on walls (Oliver and Neal 2010: Reed 2019). Anthropological, sociological, and cultural studies are interested in what insights graffiti can provide into gang-culture, youth subcultures, and identity representation (Bushnell, 1990; Phillips 1999; Bloch 2019). Geographers have considered graffiti's spatial patterns and role in shaping the character and perceptions of urban spaces, through lenses such as youth subculture, art, or crime (e.g. Creswell 1992; McAuliffe 
and Iveson 2011; Haworth et al. 2013). Despite recognition of its value from various social science disciplines, graffiti has yet to be considered seriously within scholarship on conflict and peace.

This paper attempts to address this gap by asserting that graffiti can make an important contribution to understanding local conflict dynamics, imaginaries and visions of peace and conflict. It offers a way to bring the arts, the everyday, and International Relations together. Graffiti thus can be understood as a publicly available source of local knowledge and a window into the everyday realities of conflict-affected communities. This is important for scholars and policy makers given that international peacebuilding projects have long been criticized for their failure to understand the needs of societies in which they operate and intervene (Richmond 2008; Mac Ginty and Richmond 2013). A major point of contestation is the inability of international actors to connect with local communities and understand which issues prevent peace, drive local conflict, or need prioritisation in reconstruction efforts (ibid). Taking graffiti as an alternative and dynamic commentary on everyday life in conflict-affected societies is thus an innovative way to tackle this knowledge gap and gain insights into political, social and economic issues as seen by local communities.

We recognise that there is ongoing debate about terminology of graffiti vs street art in the various fields discussed above, and that the literature uses a range of terms alongside graffiti. We have adopted the broader umbrella term graffiti in this article. We suggest that graffiti takes various forms, from tag and murals, to commissioned wall paintings. It represents diverse artistic, social, cultural, and political practices, predominantly in urban landscapes, whereby writers publicly mark their different intentions and forms of expression with potential impacts on communities (Halsey and Young 2002; Forde 2019). The term street art, in contrast, often includes other forms of public art such as sculptures or performances which we do not consider here albeit they might equally offer everyday commentary.

Graffiti is a unique form of inquiry because "it is physically located in the public domain, and what makes it quotidian, everyday art, is that it is viewed by a mass, unselected public" (Tellidis and Glomm 2019: 194). This paper will predominantly engage with graffiti as explicit articulations and representations of local community experiences. Graffiti is a global phenomenon with roots in different cultural traditions: for instance, on the US East Coast and in Latin America, graffiti was popularised through hip-hop culture (Snyder 2009), though is now often seen as an independent art form. In the Arab world, the use of calligraphy and the practices of writing in public space represent another distinct tradition of marking space (Schimmler 1990). 
This article should be read as a guiding piece that draws attention to graffiti as an understudied resource when it comes to analysing conflict dynamics and pathways to peace. It introduces an analytical framework, and a systematic way of looking at graffiti in relation to peace and conflict by drawing on examples from various conflict-affected countries to illustrate its theoretical and conceptual points and demonstrate how utilising graffiti as an analytical tool is relevant across various conflict settings. We draw on material collected by the authors during research visits to Cyprus, Colombia, Iraq, Northern Ireland, and Timor-Leste - each with its own unique tradition of graffiti and political context - and bring together existing multidisciplinary literature from a range of other locations. In doing so, the article aims to show how graffiti can be used to make sense of articulations expressed on the walls of conflictaffected societies, and highlight common elements to facilitate their interpretation. We begin with a review of the different functions pertaining to graffiti that are relevant to conflictaffected societies, namely: resistance; communication and expression; memorialisation, commemoration and inspiration or division. In doing so, we explore the question why communities and individuals might choose to mark public spaces and motivations behind the art. The article will then outline four core dimensions to consider when attempting to interpret and decode graffiti and its insights for conflict-affected societies: the spatial, temporal, political economy, and representative dimensions. This can also be viewed as an inquiry into the where, when, who and what. These four elements make up an analytical guide and enable scholars to better understand graffiti, and its political meaning and messaging in a systematic way. The four elements of analysis - the where, when, who and what - often intersect and are less distinct in reality than as portrayed in our analytical framework. However, to aid the analysis and demonstrate their individual importance, we present them separately. Thus, the article adds to the limited academic engagement with graffiti in conflict-affected societies, and offers a new approach to engaging with a different medium of socio-political commentary on ongoing conflicts and peace interventions.

\section{The value of integrating graffiti into IR and peace and conflict scholarship}

Traditionally, International Relations has been an orthodox academic discipline characterised by state-centricity and quantitative methodologies. As a political practice, it has typically favoured top-down interventions rather than bottom-up approaches to peacebuilding. Since the 1990s, several academic 'turns' have opened the academic and policy space to engage with alterative methodologies, as well as localised, everyday issues and their relevance for 
international politics. Most prominent are the so-called "local turn" (e.g. Lederach 1997; Mac Ginty and Richmond 2013) and the "aesthetic turn" (eg Bleiker 2001; 2009). The local turn in peace and conflict studies was inspired by both practical issues and theoretical shortcomings in the investigation of matters related to peace and conflict. The United Nations and other key actors' externally- and ideologically-driven peace-making and state-building agendas, for example in Bosnia-Herzegovina, Rwanda or Somalia, had, at best, limited success in the 1990s (Paffenholz 2015: 858). A primary criticism of international peace-making efforts remains that blue-print peace operations and 'one size fits all' solutions are often not compatible with the diverse cultural, socio-economic, economic, historic, and political realities of different conflictaffected societies across the globe (Mac Ginty 2008). Rather, the trend has been that they follow Western, liberal assumptions of how society, the economy and the state should operate. Consequently, the local turn has advocated for a greater understanding of distinct contexts and dynamics, and an integration and inclusion of a broader set of actors and stakeholders such as domestic civil society and local populations (Mac Ginty 2011; Paffenholz 2014: Vogel 2016). It has inspired a range of debates on hybridity, spatiality and the value of the everyday for IR (see for example these special issues: Forsyth et al. 2017; Björkdahl et al. 2019).

A second, and connected turn is the aesthetic turn that questions and diversifies our sources of knowledge. Bleiker (2009: 2) argued that engagement with aesthetic sources can broaden our understanding of world politics and help to legitimate more diverse approaches and methods to its study. Crucially, Bleiker argues that aesthetic sources can enable us to engage with people and perspectives that otherwise remain invisible. Subsequently, scholars have started to look at aesthetics and representations in international politics as a source of knowledge (eg. Lisle 2006). What these "turns" have in common is a change of focus from the macro and international to the micro, local and everyday level of society to gain additional insights alongside traditional approaches. They have enabled the everyday to become a serious area of investigation and source of knowledge for International Relations scholars focused on diverse areas of peace and conflict (Mac Ginty 2014; Distler et al 2018; Selimovic 2019). Engagement with, and analysis of, the everyday can highlight local manifestations of national and global political, economic and social processes, and can make alternative and marginalised voices visible in the public domain. As such, looking at the everyday helps scholars to uncover continuing inequalities, divisions and exclusions, common to societies across the globe and compounded in conflict-affected societies dealing with the legacies of violence. 
These theoretical debates that steam from the local and aesthetics turn constitute the foundations to legitimise wider, more qualitative approaches, to studying issues of peace and conflict. It is against the background that we argue that graffiti is of importance to International Relations as a political and cultural product created at a local level, which defines places in dynamic spatial and temporal ways. As such, graffiti becomes a valuable source of knowledge for exploring the realm of the everyday. This understanding challenges narrower views: graffiti in particular is popularly seen as either vandalism or art (Gomez 1993). This dichotomy underrepresents graffiti. It provides rich insight into societies, including different cultures, social issues, trends, and political discourses (Hanauer 2011), and spatial and territorial identities (Ley and Cybriwsky 1974; 2018); issues that are all highly pertinent in many conflict zones. Hence, graffiti can make a major contribution to studying conflict-affected societies (e.g. Morrissey and Gaffikin 2006). It highlights the struggles and concerns of the local level that are often overlooked in top-down interventions, such as social inequality, unemployment, continuing inter-communal differences, perceptions of peace, or the peace process. The focus on everyday lived experiences also engages the civilities and incivilities that occur in mundane spaces, and through the identities one performs based on place and audience (see Goffman 1956). It can highlight regional differences and gives "readers" insights into how perceptions of peace and conflict might differ across the country, contributing towards a more comprehensive and nuanced understanding of the specific context of peacebuilding. Moreover, graffiti can be used to compliment processes of peace-making and actively shape spaces as a result of its public, accessible nature.

All of the above makes graffiti particularly valuable in (post)conflict societies undergoing social and political transformation as it furthers knowledge of peace and conflict, and contributes to understandings of everyday interactions with, and in, space (Massey 2005; Gregory 2010; Björkdahl and Kappler, 2017; Vogel 2018). It is in this understanding of graffiti as a contribution to the fabric of everyday spaces, places, and identities that the presence (and absence) of graffiti, as well as its messaging, is influential and telling of a region's issues, history, and imagination. It gives an understanding of the practices of peace and conflict, and contributes to our understanding of "everyday IR" (Tellidis and Glomm 2018:191). Thus, we understand graffiti as a site of local knowledge production where international scholars and policy makers can learn more about the political problems it seeks to address and solve. First, we start with a conceptualisation of the diverse functions graffiti can have in conflict-affected societies. 


\section{Resistance}

The sight of graffiti is an element of everyday life (albeit an ever-changing medium) in many urban landscapes and thus its production warrants description as an everyday act. Much of the literature understands graffiti to be some form of visual, local subversion or resistance. The framework of everyday resistance, a classification born out of Scott's (1989) early works, is recognised by Vinthagen and Johansson (2013) as a practice in resistance in relation to dominant culture that is entrenched in the everyday act. This aligns with the recent work of Ryan (2016:3), who in the context of Latin America highlights that "street art may be seen as a symbolic re-appropriation or 'taking back' of the public space - a democratising act with anti-capitalist and/or anti-authoritarian undertones".

This conception of the street artist as an actor in resistance is not new; the (il)legality of painting on walls and changing the visual dimensions of public space has long been an act in resistance of authority (Cornish 2012). This phenomenon is evidenced across the globe: the use of graffiti during the Arab Uprisings offered a clear example of using public spaces to directly display political and social demands that challenged the status quo (Georgeon 2012; Nicoarea, 2014). Indeed, in their discussion on the Egyptian revolution, Awad, Wagoner and Glaveanu (2017: 165) highlight that before the 2011 uprisings, graffiti was not a significant part of subcultures pushing for emancipation from decades of strict political rule; however, the Arab Spring captivated "a wave of spontaneous novel artistic ways of resistance that used urban space in an innovative manner". The innovative and creative nature of this act of resistance is unpacked further by Arthur (2015), who examines the case of young artists in postindependence Timor-Leste. They use graffiti to (re)present alternative political discourses and post-conflict identity narratives that challenge that of the state. In this context, it is used as a platform for the disenfranchised, to question division, and to seek rebalancing inequalities. The physical display offers a unique tapestry where activists are not just contesting and politicising place and culture, they are creating new spaces for this exchange to occur publicly (Ryan 2016).

\section{Communication and representation}

Across the nexus of polished murals to graffiti tags, graffiti is a medium through which authors voice opinions to the everyday audiences. Writings on walls can be indicative of the attitudes and traits of a neighbourhood, city or state, with an ability to generate both social change and social tension (Ley and Cybriwsky 1974; Forde 2019; Kappler and McKane 2019). This communicative aspect is deeply embedded in graffiti of conflict-affected settings. It is an 
informal means of communication (Obeng 2000), but also an accessible form of identity representation and self-expression (Giller 1996). Miller (2002:47) encapsulates this dual function as the desire of artists to "affirm their own identities and question the values of the society they were born into". Graffiti can thus embody and articulate the values, interests, and characteristics of artists that do not expressly adhere to dominant social norms (Chaffee 1993). The very nature of the art is testament to the subversion it seeks, ${ }^{1}$ and is telling of the motivations behind those who create it. For example, messages are painted on walls by individuals who wish to express and represent themselves but perhaps feel that they lack a formal platform. In societies affected by conflict and political division, the representative and communicative functions of graffiti are particularly heightened. This is a result of the politicised nature of identity and/or space, and the transitional nature of state politics and thus formal representation. As such, graffiti warrants closer scrutiny in such contexts as it reveals the alternative political narratives and marginal attitudes that are otherwise under-represented. Further, it can be an alternative communication channel when the conflict and conflict-related issues dominate public debate and leave less room for non-conflict related themes. For example, in both the Republic of Cyprus and the Turkish Republic of Northern Cyprus, LGBTIQ communities are significantly underrepresented in parliamentary politics, relying on activism and pressure groups to raise awareness of rights protection (Papastavrou 2019). Without a formal platform, it is unsurprising that activists choose graffiti to raise awareness for the LGBTIQ community or trans rights. These messages appear on walls in Nicosia (Figure 1) and thus raise awareness for an issue that would otherwise receive little attention in Cypriot society and politics. This example attests to the idea that graffiti is a product to be read; it has a message and, as Obeng (2000: 338) notes, graffiti is "an important political communicative strategy". It is for this reason, both practical and rebellious, that graffiti is an effective tool for representation and communication. They give space to the voices of those who may otherwise not be heard, or who are perhaps mistrustful of traditional communication channels.

\section{FIGURE1}

\section{Division}

In polarised societies, any artistic resistance to division and conflict can be drawn and written on the same canvas as other expressions that seek to uphold stereotypes and reinforce division.

\footnotetext{
${ }^{1}$ We will discuss later how this is contradicted by commissioned pieces.
} 
It can function as resistance to peace and reconciliation as much as resistance to conflict and authoritarian rule. Thus, graffiti likewise offers a mechanism for intimidation and impact in everyday movements. As Amin argues (2002: 967) in the context of multicultural groups living together "everyday enactment" is "the central site of identity and attitude formation". Graffiti as art for, and in, everyday settings has a distinct opportunity to (un)consciously play a significant role in shaping the people who interact with, view, and live their lives in its presence. Such spatial influences are visible through territorial markings of tags and propaganda, sometimes associated with gang violence (Phillips 1999), as well as in more organised community projects such as murals to honour and glorify exclusivist histories (Rolston 2003). To take from the language of social capital (Putnam 2000), there is a decreased likelihood of bridging, let alone stopping, staying, or participating in a place clearly marked with unwelcome messages and hostile images (Hamilton et al. 2008). In Northern Ireland, painting gable walls of houses has long been utilised for territorialisation by memorialising a community's history and heritage and directly intimidating the 'Other', both within the context of the Troubles and post conflict (Rolston 1991, 2003). The representation of paramilitary organisations in murals in both Catholic-Nationalist and Protestant-Unionist areas contributes to political territorialisation, inter-community hostilities, and a sectarianisation of space (Bush 2013; Jarman 2005). For studies of (post-)conflict and transitional societies that are seeking to establish a more lasting peace, this particular function identifies and locates challenges to peacebuilding at a local and community level.

\section{Memorialisation, commemoration and inspiration}

Graffiti also reflects past dynamics and experiences of conflict. Martyrs, myths, 'chosen glories' and traumas (Volkan 2001), and more are re-lived and immortalised on public walls and shape the public memoryscape. Graffiti can contribute state and non-state voices to the politics of memory that can contradict or support official narratives of the past. In Medellin's (Colombia) weaker socio-economic barrios, graffiti depicts a critical reminder of the state-led military operations in their areas and the suffering it brought to the local community. Equally, it can depict imaginaries of the future, as images of peace can be portrayed during conflict, and conflict during peacetime. As argued by Read and Mac Ginty (2017: 151) "time is relational, always connected to understandings of the past and the future as well as the present". Painted in a particular moment in time, graffiti is an ideal site to examine perceptions of both peace and conflict, and distinct versions of histories, how they are told, and what imaginaries about the future exist. It offers a narrative of what is possible and what must change through 
statements like "Your Wall Cannot Divide Us" (Figure 2) in Nicosia, Cyprus. Viewing graffiti as a tool for, and in support of peace shows its potential within processes of local peacebuilding (Forde 2019), or to capture the collective imagination and create a unified story and a shared sense of belonging. In better understanding this aspirational function, both scholars and policy makers can benefit from greater insight into local attitudes. An analysis of graffiti that is commemorative and/or imaginative can reveal esteemed tropes of a community's history, identity, and aspirations, and consequently, provide deeper knowledge of the specific historical, cultural and political context.

\section{FIGURE2}

\section{Where does graffiti occure? Importance of space}

Location and spatial context are vital for understanding graffiti (Cresswell 1992; Ferrell and Weide 2010). Its location can be as important as the actual images or written content, with meanings of pieces changed or lost if dislocated from their 'spot' (Ferrell and Weide 2010). The popular 'peace' or Campaign for Nuclear Disarmament (CND) symbol, for instance, is well-recognised across the world but takes on a deeper meaning when observed in post-cold war spatial and socio-historical contexts (Brouwer 2014). Consequently, where graffiti occurs can influence the message of the same piece of art or symbols used within them. Likewise, appreciating where graffiti occurs - or does not occur (Bush 2013) - can help us understand: the physical, socio-cultural, economic and political contexts within which it was written; characteristics of the writer, such as who wrote it, how, and potentially why; who will see it and when; and associated implications for individuals, communities, and the broader urban environment. That public markings often occurs in specific spatial clusters or 'hotspots' 2 across urban landscapes (Haworth et al. 2013; Megler et al. 2014; Walker and Schuurman 2015) speaks to the significance of locational patterns in reading and interpreting graffiti. For example, in divided Cyprus, Haworth, Arthur and Lepp (2019) observed changes in graffiti quantities and content in relation to the location of the UN Buffer Zone. However, as Ferrel and Weide (2010) outline, owing to situational fluidity analysis of graffiti alone through GPS

\footnotetext{
${ }^{2}$ We use 'hotspot' here as distinct from 'spot theory', which refers to writers' perspectives in choosing locations for their pieces and the wider contextual elements that shape where graffiti is located - a 'spot' (Ferrell \& Weide 2010). We use 'hotspot' for the specific context of observed spatial patterns of graffiti occurence (clustering) as noted from GIS, urban management, and other perspectives.
} 
(location data) is insufficient, and a more nuanced approach that accounts for social interaction, cultural meanings, and shifting urban dynamics is important. We advocate that space is one important lens through which to read graffiti, but must be considered alongside others (when, who, what).

The spatial context of graffiti influences its morphology, and has been linked to appreciation or decline of streetscape value and place identity (Dovey et al. 2012). Location, and the notion of public vs private space in particular, is associated with urban management practices and graffiti (removal) policies (Haworth et al. 2013); it is also linked to graffiti presence and erasure patterns along with other factors, such as perceived graffiti quality (Dovey et al. 2012). High levels of writer interaction across spaces have been reported for some forms of graffiti, such as tags (Haworth et al. 2013), and have been linked to territorial claims related to gangs, self-proclamation, or other motivations (Lindsey and Kearns 1994). Thus, a spatial perspective on graffiti provides critical insights into the complex behavioural patterns of graffiti writing as a diverse subculture, both changing and responding to surrounding built environments, activities, and politics (Ferrell 1993; Bloch 2019).

Perceptions of graffiti and space broadly stem from cultural and socio-political attitudes to graffiti and its associations with either crime and vandalism or (street) art (Gomez 1993; Cresswell 1992). While some people find graffiti attractive, others see it aligned with criminality and social decline (Halsey and Young 2002). This has implications for the perceived character and identity of space and places. Perceptions of graffiti as crime align with spatial representations of risk and unsafety, urban abandon and social decay. Commonly connected to graffiti, the concept of "broken windows", as proposed by Wilson and Kelling (1982), asserts that a broken window left unrepaired in a neighbourhood will lead to more broken windows and further decline, when interpreted as neglect by the community. "Broken windows" infers that unchecked graffiti encourages more public markings, and potentially other crimes, defining graffiti space through notions of illegality, deprivation and undesirability. Ferrell and Weide (2010: 60) assert this theory is flawed as it relies on "static and straightforward assumptions about graffiti, its location, its meaning and its prevention." Walker and Schuurman (2015) analysed the relationship between graffiti and violent crimes, concluding that while there was a strong spatial coincidence between graffiti and violent trauma hotspots, there was no evidence to suggest causation (as per the "broken windows" concept). ${ }^{3}$

${ }^{3}$ Bloch (2019b) also makes this point, challenging broken windows notions of violent crime and graffiti correlation with added ethnographic reflection and mix methods data. 
Conversely, graffiti read as art can attract and invigorate. In post-conflict Timor-Leste, the government has actively encouraged certain graffiti projects to detract attention away from the damage caused by the conflict, still visible in the physical infrastructure of the capital city, and create a more colourful, vibrant space for tourists (Arthur 2020). Graffiti now forms a legitimate part of creative industries and tourism in cities across the world (Best 2012; Richards 2014). This is particular true for (post)conflict cities such as Belfast, Medellin, or Cairo, where graffiti tours that engage with the cities' violent past have become a 'must see' for tourists. Graffiti has even been encouraged in some locations as a method of deterring it elsewhere (e.g. Ovenden 2007), further demonstrating its ability to define space in divergent ways.

Urban space also influences graffiti presence and morphology (e.g. Ferrell and Weide 2010). The globalisation of graffiti in morphology and practice has meant that locations around the world that are vastly different in some ways can exhibit similar graffiti techniques and styles, yet place-specific nuances unique to individual locations remain (Chmielewska 2007). Evidence from Bristol suggests that the associated risk (danger, accessibility or illegality) of a location influences the quality and amount of graffiti (Parno 2010). The presence of other graffiti at a location may inform graffiti occurrence, style and quality, especially for hip-hop styles of graffiti such as tags or throw-ups (Halsey and Young 2002). By contrast, the absence of graffiti can contribute to spatial and temporal patterns of graffiti, with 'blank' walls often seen as 'negative space' and opportunities for graffiti writers to transform spaces (Halsey and Young 2006). Graffiti management approaches aiming to eradicate graffiti from particular spaces through rapid removal or harsh penalties can deter writers, in turn influencing space. In post peace-agreement Northern Ireland a notable lack of graffiti has been in part attributed to police enforcement of laws that criminalize graffiti (among other factors, such as an absence of public space) (Bush 2013). However, such harsh approaches have influenced graffiti in other ways, such as by encouraging quicker forms of graffiti such as tags, arguably the form the public desire least (Shobe and Banis 2014), and through hotspot locational shifts rather than graffiti reduction (Haworth et al. 2013). Changes to physical spaces have been shown to influence graffiti occurrence in conflict-affected societies, such as the increased painting of graffiti as a mechanism for protest and reclamation by artists and activists following the erection of segregating walls in downtown Cairo (Abaza 2013).

\section{When does graffiti occur? Spacetime and public art}

Graffiti is inherently temporal and spatial and there is a deep connection between these factors. Graffiti is painted on a wall, it can then be painted over, and new works can replace it (Haworth 
et al. 2013; Ryan 2016). Correspondingly, the space itself changes over time to reflect the graffiti, lack of graffiti, new graffiti, and the messages portrayed by it, which in turn influences people's relationship to the space (May and Thrift 2003). The temporal nature of graffiti can change the way space is used at different times, as "society is fundamentally spatial" and "therefore that what exists in space will affect how society plays out" (Gusic 2019: 49). Reflecting the relationship to the space, graffiti can be both inclusive and exclusive and happens during both times of peace and conflict. For instance, the Islamic State (IS) used graffiti during its caliphate as an exclusionary measure against those that did not conform to its version of conservative Sunni Wahabi Islam, particularly Christians and Yazidis. ${ }^{4}$ However, following the territorial defeat of IS in Iraq, a range of groups - from youth groups, to Yazidis, to a senior citizen group - began covering over IS' messages and replacing them with peaceful and inclusionary messages. ${ }^{5}$

Graffiti is temporal in that it represents a specific time, and attitudes to the piece change over time both negatively and positively (Phillips 1989). In the case of IS, the work represented the dynamics of the time and had a direct impact on what was possible in relation to graffiti, or indeed the space. Due to IS' hegemonic and brutal control of the area, graffiti of peace or resistance was not possible without violent reprisal (O'Driscoll 2016). However, following its defeat, inclusionary art was once again possible, and exclusionary messages then became socially unacceptable, thus demonstrating how temporality and changing attitudes or dynamics influence graffiti and the space.

Therefore, the local dynamics and attitudes at the time also have to be considered when examining graffiti in relation to peace and conflict; the lack of peaceful and inclusionary graffiti in Mosul did not mean that these sentiments did not exist but since resistance to IS was met with execution, such a visible display was avoided. The fact that inclusionary graffiti was utilised so soon after IS' defeat suggests that the sentiments existed but the rule of IS prevented it. Further connecting to its temporal spatial nature, graffiti was used by IS to police the community, setting about rules and creating fear of repercussions, changing the people's relationship with the space. In this way, graffiti in conflict settings can be much like gangrelated graffiti as it is used to mark territory and change the way people can act in the territory and signals who is welcome. Like gang-related graffiti, this changes over time as the territory controlled expands or shrinks (Brown 1978; Brighenti 2010).

\footnotetext{
${ }^{4}$ See for example, https://twitter.com/OpenDoorsyouth/status/877895713564246016

${ }^{5}$ https://alshahidwitness.com/street-art-peace-mosul/
} 
The importance of temporality and graffiti is underlined in societies recovering from conflict, precisely because of the transitional and fragile nature of peace. This has been exemplified in post-conflict Northern Ireland, where exclusionary graffiti was challenged almost in real time. In May 2019, following the murder of journalist Lyra McKee, New Irish Republican Army (NIRA) graffiti about the "unfinished revolution" appeared in the Creggan Estate in Derry-Londonderry, warning that informers would be executed. ${ }^{6}$ However, the graffiti was painted over and replaced with messages such as "our differences make us stronger"? Previously in Northern Ireland, such exclusionary messages would have been accepted by the community and left, whereas peaceful, inclusionary messages perhaps would not have been accepted, further demonstrating the significance of temporality to graffiti. However, as times have changed since the height of The Troubles, a community tired of violence and looking for peace quickly replaced the NIRA-linked graffiti. Moreover, this demonstrates that the NIRA does not have the same control or instil the same fear as it once did, or as IS did in Mosul, and importantly how graffiti can be used to understand the local dynamics and perceptions of the conflict.

Graffiti is temporal as it is continuously replaced; however, with the popularity of social media, particularly utilising images, a new temporal dimension is introduced. It can be a rich data source for the analysis of graffiti. It enables scholars to access photos of graffiti from conflict zones when travel is unfeasible (for financial, security, timing, or environmental considerations). It preserves visual data when the original pieces are quickly removed for political or aesthetic reasons. For example, during the October 2019 Iraq protests, protestors used graffiti as a means portraying their grievances (see Figure 3). Although many were painted over in an attempt to silence protestors, photos remained through the social media accounts of those involved on the ground. This means that local sentiments and messages can still be read in authoritarian environments that quickly remove critical messages.

\section{FIGURE3}

Likewise, the longitude of digital imagery often can misrepresent local dynamics. For instance, during the battle against IS in Iraq there was an influx of international journalists to the region who embedded with the various security forces and witnessed IS-controlled territory

\footnotetext{
${ }^{6} \mathrm{https}: / /$ twitter.com/LeonaONeill1/status/1123884930809958400

7 https://twitter.com/LeonaONeill1/status/1125314577133187073
} 
being retaken. Many of these took photographs of IS graffiti and posted on their social media accounts to their considerable number of followers. This represented a very distinct and brief time where IS no longer controlled the territory, but the local population had not yet returned. Yet, digitally this period is visually dominant. Additionally, as IS was defeated, international media attention waned and there were considerably fewer journalists in the region. Thus, the community actions to replace the exclusionary messages with inclusionary graffiti did not receive the same attention. ${ }^{8}$ From a spatio-temporal view, the international and the local audiences see the same space at different times. Whilst the exclusionary view of the space lives on internationally to a greater extent, locally the space now portrays inclusionary messages, demonstrating a society trying to move on from the conflict. These contradictory, temporallyinfluenced perceptions affect how the post-conflict society is viewed, which in turn, can prevent some of the reconciliatory messages coming to the fore. This parallel reality can negatively impact peacebuilding, as opportunities are missed, particularly where peacebuilding actors fail to connect to everyday lived realities. In other words: while social media preserves the visual data, it removes it from its context which might impact on, and potentially lead to misinterpretations of its message and its importance for the local context.

\section{Who paints - who pays - who provides space? Looking behind the picture}

To academically analyse graffiti, it is essential to understand who produced (and/or commissioned) it. Questions of anonymity and visibility are key; artists may want to protect their identity and write themselves out of the artwork. Visibility is often linked to debates about the commodification of art and artwork or professionalization and commercialisation of memory spaces (Björkdahl and Kappler 2019). For example, in post-war Colombia, graffiti can provide an alternative income to drug dealing and a way out of poverty and a culture of toxic masculinity. In Medellin, once the centre of Pablo Escobar's drug trade and today still in the hands of competing drug gangs, the streets are flooded with (commissioned) pieces of art that contain Instagram and Twitter handles to follow the artists. That can be helpful in the research process, as it enables researchers to easily trace artists, however, it also shows that many pieces have from the outset different, and often non-political, functions: some are to beautify touristic neighbourhoods; some are commissioned for commercial reasons to advertise hostels and restaurants (figure 4).

\footnotetext{
${ }^{8}$ One of the authors lived in Erbil, the base for many international journalists, before, during and after the Islamic State's reign and witnessed these dynamics.
} 


\section{FIGURE4}

Others are political in nature and intent, revealing how public art for consumption can be contentious with the intention of the artist. The barrio of Comuna 13, infamously known as one of the most dangerous areas of Medellin, is home to hundreds of pieces of graffiti that engage with both the violent past and present of the neighbourhood, as well as hopes for the future. The colourful and vibrant art now brings tourists en masse to Comuna 13 to join guided graffiti walking tours. According to Tripadvisor, their aim is to provide a "unique cultural experience exploring the miraculous transformation of this vibrant community". ${ }^{9}$ However, the graffiti tour is integral to the community's socio-economic development (Naef 2018). In conjunction with the many daily tours that take place, a range of shops, cafes and eateries have opened to serve the groups of tourists that venture to the barrio on a daily basis (ibid). This leads some local artists, who mainly perceive their art as resistance, to be critical of the tour for being a 'product' rather than a local expression. Indeed, the pieces shown in Comuna 13 follow some rules defined by a neighbourhood committee: they must be pre-approved, painted in vibrant colours with new designs 'better' than the old ones, and have a peaceful message. ${ }^{10}$ While the tour guides try to portray a positive picture of the transformation of the community, including the acceptance of foreigners in the area, it is possible to spot the occasional small, unofficial graffiti that reads "Tourists Out!". ${ }^{11}$

The case of Medellin points to deeper tensions in the graffiti debate. How do we engage with the commodification of art, especially graffiti art, when trying to read social realities rather than curated messages? This relates to questions about whether the piece was produced out of a social disagreement or as a way to generate an income (e.g. Merrill 2015). Moreover, it raises the question as to whether or not we can actually read the 'local voice' in the streets. Do street artists need to be unpaid to be radical, or can they make a living from their political artwork and still criticise the political and social status quo? In contrast, conventional art and arts centres (such as galleries, museums or heritage sites) can, and from a societal point of view, should be state funded. Graffiti can act as a counterweight to these official narratives as discussed above, and therefore are expected to be independent and not to operate within capitalist frameworks

\footnotetext{
${ }^{9}$ https://www.tripadvisor.ca/Attraction_Review-g297478-d7178986-Reviews-Comuna_13_Graffiti_TourMedellin Antioquia Department.html

${ }^{10}$ Information provided by graffiti tour guide, personal conversation, $4^{\text {th }}$ February 2019 , Medellin.

${ }^{11}$ Field observation, $4^{\text {th }}$ February 2019, Medellin.
} 
in order to remain authentic. It can, however, also mean, that graffiti at times represents the voice of (economic) power rather than local resistance (see Kappler and McKane (2019) for the idea of curating the city). As such, it is vital to pay attention to the questions of who finances graffiti and who provides and regulates spaces.

\section{What can we read?}

In order to analyse graffiti in a way that incorporates resisting and subversive characteristics, it is useful to firstly consider it as a cultural product (see Cohen 1972; Clarke 1974; Clarke et al. 1976; MacDonald 2002). The resistance to dominant social norms that typifies graffiti becomes most clear in visual forms such as graffiti because by making this challenge visible, rebellion and subcultures are most effective. Hebdige argues that "the challenge to [cultural] hegemony which subcultures represent is not issued directly by them. Rather it is expressed obliquely, in style [...] at the profoundly superficial level of appearances: that is at the level of signs" (1979: 17; emphasis added). These visual signs are symbolic representations of the identities and values of artists who seek to challenge the cultural hegemony or dominant culture in a society (see Clarke et al. 1976: 39-42). Thus, if we examine graffiti as a symbolic form of representation, we can gain deeper knowledge of the identities and ideals projected, their symbolic meanings, and the influence the artist seeks to have on their community.

Symbolic forms, in their broadest sense, are the objects and devices that give form to intangible abstractions of identity, culture, heritage, and ideology, allowing individuals to visualise and understand them (Firth 1973). They can act as boundary markers, delineating differences between one collective and another; they can also be used to unite a diverse group of people under a single identity, whether it be local, national or transnational in nature (Arthur 2019). As such, symbolic forms and representations in graffiti constitute windows into the identities and ideas of a particular community or area. Understood within their specific cultural, political, historical context, they can reveal much about the motivations behind the art, the specific message it communicates, and the intended audience. For example, certain cultural icons or historic figures will hold great significance for one community and not for another. Further, internationally-recognised symbols indicate a more universal message and a much broader target audience, such as the Anarchist 'A' and the CND peace symbols (Figure 5), signifying identification with two global ideological movements. These visuals objectify intangible and complex political beliefs, emitting their meaning instantaneously and accessibly. 
In addition to the insight afforded by pictorial representations, textual communications through graffiti are equally telling. This is of particular importance for understanding graffiti in conflict-affected societies since it discloses unique information about the specific local context in which it is found, key to adopting everyday approach to studies of peace and conflict. In text-focused pieces, there is the obvious literal message that is written or painted on a wall to be analysed in context, but the composition of the message is also important to consider. First, the choice of language is important to note. Language is often a primary marker of ethnic difference and community boundaries and in ethnically diverse or culturally divided societies, language choice can be indicative of the author, audience, and the heritage within which to contextualise the text. As Jørgensen notes, "[the] languages have not been chosen at random, but have been chosen because of the stereotypical values more or less ascribed to them, as well as the connotations carried by the individual words" (2008: 247). Conversely, English is often adopted in pieces that are intended for an international audience, such as graffiti close to the UN Buffer Zone in Cyprus or UN and NGO headquarters in Dili, Timor-Leste. Within discussions of language, the phenomenon of code-mixing or code-switching also important to consider, that is "the graffiti discourse [in which] participants switch from one language to another within the same sentence" (Obeng 2000: 360-361). Such wordplay can have multiple objectives, to obfuscate meaning, reflect cultural diversity and inclusivity, or comment on social and cultural capital associated with language (Arthur 2015). Second, the grammatical constructions that underpin the message can reveal intentionality and target audiences. Inclusive, collective pronouns such as 'we' and 'us' foster a sense of closeness within a community, whereas the exclusive pronouns of 'you' and 'them' denote difference and otherness (Obeng 2000: 342). When analysed within a (post-)conflict context, such messaging and communications can have real impacts on social relations and interactions, or the lack thereof, and reflect challenges to peacebuilding at this local level.

\section{Conclusion}

Graffiti has much to offer to the study of both peace and conflict. In this article, we argued that it can be a vital source of knowledge production, and therefore a valuable resource for scholars and peacebuilding practitioners in understanding local challenges that prevent building sustainable peace. From the perspective of the artist, it can be a tool in transitional and conflictaffected societies for numerous purposes: to challenge the status quo; as a platform where 
formal governance and political representation are debated or (re)construction, or where minority and marginalised voiced find public space to "talk"; to reinvigorate the urban landscape; and to maintain division and hostilities. More importantly from the perspective of our article, graffiti can enable the reader to understand how peace and conflict are viewed at the local level away from elite conversations. Such an understanding not only allows for the development of polices that connect to local needs and desires, but can demonstrate what is (im)possible within the local dynamics as it offers multifaceted and direct ways to resonate with the everyday experiences of those who live in (post)conflict settings. Importantly, our examples demonstrate that while graffiti is universally used, it is not defined by a singular context or culture. It is therefore important to analyse graffiti within its original spatial and temporal setting in order to understand the complexity and way that it intertwines with everyday lives in settings of peace and conflict. The resulting knowledge can be beneficial for both academics and policy makers at local, national, and international levels. To that end, the article has offered a guide through which to do so. It can be utilised by academics, policy makers, and international non-governmental organisations to ensure a better connection to local everyday realities and unheard voices

Second, and following from the above, the study of graffiti offers a great deal to the emerging themes in the field of peace and conflict studies, in particular with reference to emerging conceptual debates about spaces, temporality and the everyday. These insights span beyond the IR-peace studies nexus they are framed within and require a more creative, multidisciplinary approach to peace than has previously existed. This multidisciplinary approach offers much to different cognate fields - the information gap between international and local agendas such as humanitarianism or development studies would benefit from more systematic engagement with graffiti.

In recognising the growth and use of graffiti, this article has suggested that it is not only a representation of the everyday and its socio-political context, but it creates and shapes space and place by marking territory, economically reviving and pacifying areas, and creating in- and exclusive environments for different national, religious and ethnic groups. By looking at the where, when, who and what, graffiti can provide dynamic and near-real time insights into conflict-affected societies. Combined, these elements paint a picture of what graffiti tells us about local dynamics, everyday peace and conflict, differential power distributions, and competing imaginaries of a post-conflict order. In support of these aims, there is scope and justification for further research and data collection that could take the form of in-depth case 
studies, methodological innovation and the compilation of a large visual database that could be drawn upon to analyse and engage with works globally and contextually. 


\section{References}

Abaza, M. (2013) Walls, segregating downtown Cairo and the Mohammed Mahmud Street graffiti. Theory, Culture \& Society, 30(1): 122-139.

Amin, A. (2002) 'Ethnicity and the multicultural city: living with diversity', Environment and Planning A, 34: 959-980.

Arthur, C. (2015) 'Writing National Identity on the Wall: the Geração Foun, Street Art and Language Choices in Timor-Leste' Cadernos de Arte e Antropologia, 4(1): 41-63.

Arthur, C. (forthcoming 2020). Street art in Timor-Leste: creative (re)constructions of identity in times of crisis. In Zaimakis Yiannis, Ricardo Campos, and Andrea Pavoni (eds) Street Politics in Critical Times: Street art, graffiti and artistic activism across the world. Berghan Books.

Arthur, C. (2019) Political Symbols and National Identity in Timor-Leste. Cham: Palgrave Macmillan.

Awad S.H., Wagoner B., Glaveanu V. (2017) 'The Street Art of Resistance' In: Chaudhary N., Hviid P., Marsico G., Villadsen J. (eds) Resistance in Everyday Life. Springer, Singapore.

Best, G. (2012) In the eye of the beholder: Street art, landscape, and the tourist gaze refocused. CAUTHE 2012: The new golden age of tourism and hospitality; Book 2; Proceedings of the 22nd Annual Conference. Melbourne, Vic.: La Trobe University, 61-65.

Björkdahl et al. (2019). Everyday international relations: Editors' introduction, Cooperation and Conflict 54(2), 123-130.

Björkdahl, A. and Kappler, S. (2017) Peacebuilding and spatial transformation: Peace, space and place. Taylor \& Francis.

Björkdahl, A and S. Kappler (2019) The Creation of Transnational Memory Spaces: Professionalization and Commercialization, International Journal of Politics, Culture and Society, online first.

Bleiker, R. (2001) The aesthetic turn in international political theory. Millennium, 30(3): 509533.

Bleiker, R. (2009) Aesthetics and World Politics. London: Palgrave.

Bloch, S. (2019) Broken Windows Ideology and the (Mis) Reading of Graffiti. Critical Criminology, 1-18.

Bloch, S. (2019b) An On-the-Ground Challenge to Uses of Spatial Big Data in Assessing Neighborhood Character. Geographical Review,1-14.

Brighenti, A. (2010) At the Wall: Graffiti Writers, Urban Territoriality, and the Public Domain. Space and Culture, 13(3): 315-332.

Brouwer, K. (2014) "The Wall as a Silent Witness to it All: A Preliminary Introduction to Conflit-Related Graffiti." Desipientia, 21(2): 24-28.

Brown, W. K. (1978) Graffiti, Identity and the Delinquent Gang, International Journal of Offender Therapy and Comparative Criminology, 22(1): 46-48.

Bush, K. (2013) The politics of post-conflict space: the mysterious case of missing graffiti in 'post-troubles' Northern Ireland. Contemporary Politics, 19(2): 167-189.

Bushnell, J. (1990) Moscow Graffiti: Language and Subculture, Boston: Unwin Hyman.

Chaffee, L.G. (1993) Political protest and street art: Popular tools for democratization in Hispanic countries: Vol. 40 (Westport: Greenwood Publishing Group)

Chmielewska, E. (2007) Framing context: graffiti and place. Space and Culture,10(2): 145169. 
Clarke, J., Hall, S., Jefferson, T and B. Roberts (1976) 'Subcultures, Cultures, and Class', in Stuart Hall and Tony Jefferson (eds), Resistance through Rituals, London: Routledge, 9-74.

Clarke, M. (1974) 'On the Concept of "Subculture”, British Journal of Sociology, 25(4): 42841.

Cohen, P. (1972) 'Sub-cultural Conflict and Working Class Community', Working Papers in Cultural Studies, 2 Birmingham: University of Birmingham.

Cornish, F. (2012) 'The Social Act of Protest: The crowd, authorities, and a contentious issue' In B. Wagoner, E. Jensen, and J. A. Oldmeadow (Eds.), Culture and social change: Transforming society through the power of ideas. Charlotte, NC: Information Age.

Cresswell, T. (1992) The Crucial 'Where' of Graffiti: A Geographical Analysis of Reactions to Graffiti in New York. Environment and Planning D: Society and Space, 10(3): 329344.

Distler, W. Stavrevska, E. and Vogel, B. (2018) Economies of peace: Economy formation processes and outcomes in conflict-affected societies, Civil Wars 20(2): 139-150

Dovey, K., Wollan, S., and Woodcock, I. (2012) Placing graffiti: creating and contesting character in inner-city Melbourne, Journal of Urban Design, 17(1): 21-41.

Ferrell, J. (1993) Crimes of style: Urban graffiti and the politics of criminality. New York: Garland.

Ferrell, J. and Weide, RD. (2010) Spot theory. City, 14(1-2), 48-62.

Firth, R. (1973) Symbols: Private and public. Ithaca: Cornell UP.

Forde, S. (2019) Movement as Conflict Transformation: Rescripting Mostar, BosniaHerzegovina, London, Palgrave.

Forsyth et al. (2017) Hybridity in peacebuilding and development: a critical approach, Third World Thematics: A TWQ Journal, 2:4, 407-421.

Georgeon, D. (2012) 'Revolutionary Graffiti: Street Art and Revolution in Tunisia' Wasafiri, 27(4): 70-75.

Giller, S. (1996) Graffiti: Inscribing Transgression on the Urban Landscape. Available at: https://www.graffiti.org/faq/giller.html

Goffman, E. (1956) The Presentation of Self in Everyday Life (Monograph No.2). Edinburgh: University of Edinburgh Social Sciences Research Centre.

Gomez, M.A. (1993) The writing on our walls: finding solutions through distinguishing graffiti art from graffiti vandalism. University of Michigan Journal of Law Reform, 26(3): 633-708.

Gregory, G. (2010). War and Peace. Transactions of the Institute of British Geographers (35): 154-186.

Gusic, I. (2019) The relational spatiality of the postwar condition: A study of the city of Mitrovica. Political Geography, 71, 47-55.

Halsey, M. and Young, A. (2002) The meanings of graffiti and municipal administration. Australian and New Zealand Journal of Criminology, 35(2): 165-186.

Hamilton, J. et al. (2008) Segregated Lives: Social Division, Sectarianism and Everyday Life in Northern Ireland. Belfast: Institute for Conflict Research.

Hanauer, D.I. (2011) The discursive construction of the separation wall at Abu Dis: Graffiti as political discourse. Journal of Language and Politics, 10(3): 301-321.

Haworth, B.T., Arthur, C. and Lepp, E. (2019, July 10). Graffiti in Cyprus paints a rich and complex picture of this divided society. The Conversation. Available at https://theconversation.com/graffiti-in-cyprus-paints-a-rich-and-complex-picture-ofthis-divided-society-119437

Haworth, B., Bruce, E., and Iveson, K. (2013) Spatio-temporal analysis of graffiti occurrence in an inner-city urban environment. Applied Geography, 38: 53-63. 
Hebdige, D. 1979. Subculture: The Meaning of Style, London: Routledge.

Jarman, N. (2005), Changing places, moving boundaries: the development of new interfaces. Shared Space (1): 9-19.

Jørgensen, J.N. (2008) Urban wall languaging. International Journal of Multilingualism, 5(3): 237-252.

Kappler, S. and McKane, A. (2019) "Post-conflict Curating": The Arts and Politics of Belfast's Peace Walls. de arte, 1-18.

Kindynis, T. (2018) Bomb alert: Graffiti writing and urban space in London. British Journal of Criminology, 58(3).

Lederach, J.P. (1997) Building Peace: Sustainable Reconciliation in Divided Societies. Washington, DC: United States Institute of Peace Press.

Lefebvre, H. (1984). Everyday life in the modern world. New Brunswick and London: Transaction Publishers.

Ley, D. and R. Cybriwsky (1974) 'Urban graffiti as territorial markers' Annals of the Association of American Geographers, 64(4): 491-505.

Ley, D. and Cybriwsky, R. (2018) Urban graffiti as territorial markers. In: Johnson (Ed.) Culture and Society, Routledge, 143-157.

Lindsey, D. G., \& Kearns, R. A. (1994). The writing's on the wall: Graffiti, territory and urban space in Auckland. New Zealand Geographer, 50(2), 7-13.

Lisle, D. (2006). The global politics of contemporary travel writing. Cambridge University

Press.

Macdonald, N. (2002) The Graffiti Subculture: Youth. Masculinity, and Identity in London and New York (New York: Palgrave Macmillan)

Mac Ginty, R. (2008) Indigenous peace-making versus the liberal peace. Cooperation and conflict, 43(2): 139-163.

Mac Ginty, R. (2011) International peacebuilding and local resistance: Hybrid forms of peace. Springer.

Mac Ginty, R. and Richmond, OP. (2013) The local turn in peace building: A critical agenda for peace. Third world quarterly, 34(5), 763-783.

Mac Ginty, R. (2014). 'Everyday peace: Bottom-up and local agency in conflict-affected societies', Security Dialogue, 45 (6): 548-564.

Massey, D. (2005). For Space, Sage: London.

May, J., and Thrift, N. (Eds.). (2003). Timespace: geographies of temporality. New York: Routledge.

McAuliffe, C. and Iveson, K. (2011) Art and crime (and other things besides...): Conceptualising graffiti in the city. Geography Compass, 5(3),128-143.

Megler, V., Banis, D., and Chang, H. (2014). Spatial analysis of graffiti in San Francisco. Applied Geography, 54: 63-73.

Merrill, S. (2015) Keeping it real? Subcultural graffiti, street art, heritage and authenticity, International Journal of Heritage Studies, 21:4, 369-389

Miller, IL. (2002) Aerosol Kingdom: Subway Painters of New York City, Jackson: University Press of Mississippi.

Morrissey, M., and Gaffikin, F. (2006) Planning for peace in contested space. International Journal of Urban and Regional Research, 30(4): 873-893.

Naef, P. (2018) Touring the 'comuna': memory and transformation in Medellin, Colombia, Journal of Tourism and Cultural Change, 16(2): 173-190.

Nicoarea, G. (2014). Interrogating the Dynamics of Egyptian Graffiti: from Neglected Marginality to Image Politics. Revista Română de Studii Eurasiatice, An X, 1-2: 171186. 
Obeng, S.G. (2000) 'Doing politics on walls and doors: A sociolinguistic analysis of graffiti in Legon (Ghana)' Multilingua, 19(4): 337-365.

O'Driscoll, D. (2016) The Future of Mosul: Before, During, and After the Liberation. MERI Policy Reports, 1-60.

Oliver, J. and Neal, T. (2010)Wild Signs: Graffiti in Archaeology and History. Oxford: Archaeopress.

Ovenden, C. J. (2007) Brisbane's unique anti graffiti strategy: artforce - an empirical report. In B.C. Council (Ed.) (pp. 23). Brisbane, Australia: Brisbane City Council.

Paffenholz, T. (2014) International peacebuilding goes local: analysing Lederach's conflict transformation theory and its ambivalent encounter with 20 years of practice. Peacebuilding, 2(1), 11-27.

Paffenholz, T. (2015) Unpacking the local turn in peacebuilding: a critical assessment towards an agenda for future research. Third World Quarterly, 36(5), 857-874.

Papastavrou, S. (2019) Women's Organizations for Peace: Moving beyond the Rhetoric of the Cyprus Problem. Doctoral thesis, University of Toronto, available from https://tspace.library.utoronto.ca/handle/1807/94062

Phillips, P.C. (1989) Temporality and Public Art. Art Journal, 48(4), 331-335. doi:10.1080/00043249.1989.10792651

Phillips, S.A. (1999) Wallbangin': Graffiti and Gangs in L.A. Chicago: University of Chicago Press.

Putnam, R. (2000). Bowling Alone: The Collapse and Revival of American Community. London: Simon and Schuster.

Read, R. and Mac Ginty, R. (2017) The temporal dimension in accounts of violent conflict: A case study from Darfur. Journal of Intervention and Statebuilding, 11(2), 147-165.

Reed, K. (2019) 'The Prison, By God, Where I Have Found Myself': Graffiti at Ellis Island, New York c.1900-1923' Journal of American Ethnic History, 38(3): 5-35.

Richards, G. (2014) Creativity and tourism in the city. Current Issues in Tourism, 17(2): 119144.

Rolston, B. (1991) Politics and painting: Murals and conflict in Northern Ireland. London: Associated University Presses.

Rolston, B. (2003). 'Changing the Political Landscape: Murals and Transition in Northern Ireland' Irish Studies Review, 11(1): 3-16.

Ryan, H. E. (2016). Political street art: Communication, culture and resistance in Latin America. New York: Routledge.

Schwarz, R. (2005) 'Post-conflict peacebuilding: the challenges of security, welfare and representation', Security Dialogue, 36(4): 429-446.

Scott, J.C. (1989). 'Everyday Forms of Resistance', Copenhagen Papers (4): 33-62.

Selimovic, J. M. (2019). Everyday agency and transformation: Place, body and story in the divided city. Cooperation and Conflict, 54(2), 131-148.

Snyder, G. (2009) Graffiti Lives: Beyond the Tag in New York's Urban Underground (Alternative Criminology). New York: New York University Press.

Schimmel, A. (1990) Calligraphy and Islamic Culture. London: I.B. Tauris.

Shobe, H., and Banis, D. (2014) Zero graffiti for a beautiful city: the cultural politics of urban space in San Francisco. Urban Geography, 35(4): 586-607.

Tellidis, I., and Glomm, A. (2018) Street art as everyday counterterrorism? The Norwegian art community's reaction to the 22 July 2011 attacks. Cooperation and Conflict, 54(2): 191-210.

Vinthagen, S. and Johansson, A. (2013) "Everyday Resistance": Exploration of a Concept and its Theories, Resistance Studies Magazine, 1. Available at: 
https://www.researchgate.net/publication/303516884_Everyday_Resistance'_explorati on_of_a_concept_its_theories.

Vogel, B. (2018) Understanding the impact of geographies and space on the possibilities of peace activism. Cooperation and Conflict, 53(4): 431-448.

Volkan, Vamik D. (2001) Transgenerational transmissions and chosen traumas: an aspect of large-group identity, Group Analysis (34): 79-97.

Walker, B.B. and Schuurman, N. (2015) The pen or the sword: a situated spatial analysis of graffiti and violent injury in Vancouver, British Columbia. The Professional Geographer, 67(4): 608-619.

Wilson, J.Q., and Kelling, G.L. (1982) The police and neighborhood safety: broken windows. The Atlantic Monthly, 127: 29-38.

Wilson, P. (1987). Graffiti and Vandalism on Public, Transport No. 6 Research Brief. Canberra: Australian Institute of Criminology. 